\title{
The reasons for low intrapopulation genetic variation in Lamium incisum Willd.
}

\author{
Katarzyna Wąsowicz, Monika Szczecińska \& Jakub Sawicki
}

The reasons for low intrapopulation genetic variation in Lamium incisum Willd.- Čas. Slez. Muz. Opava (A), 60: 79-84, 2011.

\begin{abstract}
The paper presents results of a study which aim was preliminary screening of intrapopulation genetic variability in Lamium incisum Willd. This weed species is rarely distributed in Poland and lessening its count during the last years. As a plant inhabiting anthropogenic sites it is exposed to extreme conditions and disturbances caused mostly by the progressive intensification of agriculture. In order to investigate the genetic variability of the selected population markers of ISSR category were used. The analysis of chosen individuals with use of three ISSR primers revealed total of 49 loci, of which only 15 were polymorphic. Nei's gene diversity index $\left(\mathrm{H}_{\mathrm{E}}=0.099\right)$ and the mean number of alleles per locus $\left(\mathrm{A}_{\mathrm{E}}=1.160\right)$ indicated low genetic diversity within the examined population. The research presented in this paper allows for a better learning of the genetic variability of the investigated species and considers probable factors influencing its level.

Key words: Lamium incisum, ISSR, population genetics, genetic variability
\end{abstract}

\section{Introduction}

Lamium incisum Willd. (syn.: Lamium hybridum Vill. s. str.; Lamium hybridum Vill. ssp. dissectum (With.) Gams,; Lamium dissectum With.) (Lamiaceae) is a weed of crop plants also appearing in ruderal communities. It is an archeophyt classified as Archaeophyta Antropogaena which appearance and spreading most probably was under the big influence of agronomic exertions (Zając 1988). This plant's main geographic range covers Northern and Central Europe but sporadically it is found in Southern Europe and also on the north of Africa. Eurasian and African continent is a natural range of the species but presently L. incisum occurs in North America as well, where it was dragged and dispersed by humans (Mennema 1989, Taylor 1991). The occurrence of the species in Poland is limited mostly to the northern part of the country. Southernmost localities in Poland were found in Lodz Hills (Wzniesienia Łódzkie) which is a part of Masovian Lowland (Nizina Mazowiecka). The species is rare in Poland and lessening its count during the last years (Korniak \& Hołdyński 1987, Warcholińska 1993). Probably this state is caused by the progressive intensification of agriculture which entails the common usage of herbicides. The reason might also lie in the biology of the species.

Crop fields and ruderal sites where L. incisum occurs are habitats particularly marked by extreme conditions and anthropogenic disturbances what makes this plant especially exposed to sudden number reduction. Significant number of individuals eliminated in one site entails partial loss of alleles from genetic pool. In the case of such an occurrence the population is threatened with loss of allelic richness and a higher degree of homozygosis.

It is commonly known that rare species consisting of dispersed small populations maintain a low level of genetic variation (Lomnicki 2002). Genetic diversity is one of the most important factors in the survival of population, for it has a positive influence on the adaptive flexibility of species in the presence of fluctuating biological and abiotic determinants (Vrijenhoek 1994). The bigger genetic variation of a weed the better chance for adaptation to new conditions and survival in a changing environment.

Estimation of genetic diversity level facilitates valuation of population's condition and also enables concluding about going processes. The aim of this study was preliminary 
screening of intrapopulation genetic variability in L. incisum on the example of the most numerous from all found populations of this rare weed.

\section{Material and Methods}

Lamium incisum is an annual herbal plant with pink, sessile flowers collected in verticillasters in the axes of the floral leaves. Flowers are of dorsal symetric with bilabiate corolla, the calyx is campanulate with subequal teeth. Under the climate conditions of Poland the species blooms from March to November. The fruit consist of four obvoid nutlets provided with elaiosomes (Szafer et al. 1986).

L. incisum is an allotetraploidal species, which phylogenesis still isn't clear enough. It is thought to be a hybrid of $L$. purpureum L. and L. bifidum Crillo. Nowadays there are no confirmed events of hybrids arising nor crossbreeding with other Lamium species.

During the field research carried out in northern Poland in the years 2009-2010 13 localities of L. incisum were found. The most numerous population composed of over 50 specimens was found in the northeastern Poland near the village of Rodnowo (GPS coordinates: 20 $\left.39^{\prime} 40.09^{\prime \prime} \mathrm{N}, 54^{\circ} 13^{\prime} 47.61^{\prime \prime} \mathrm{E}\right)$ (Fig. 1).

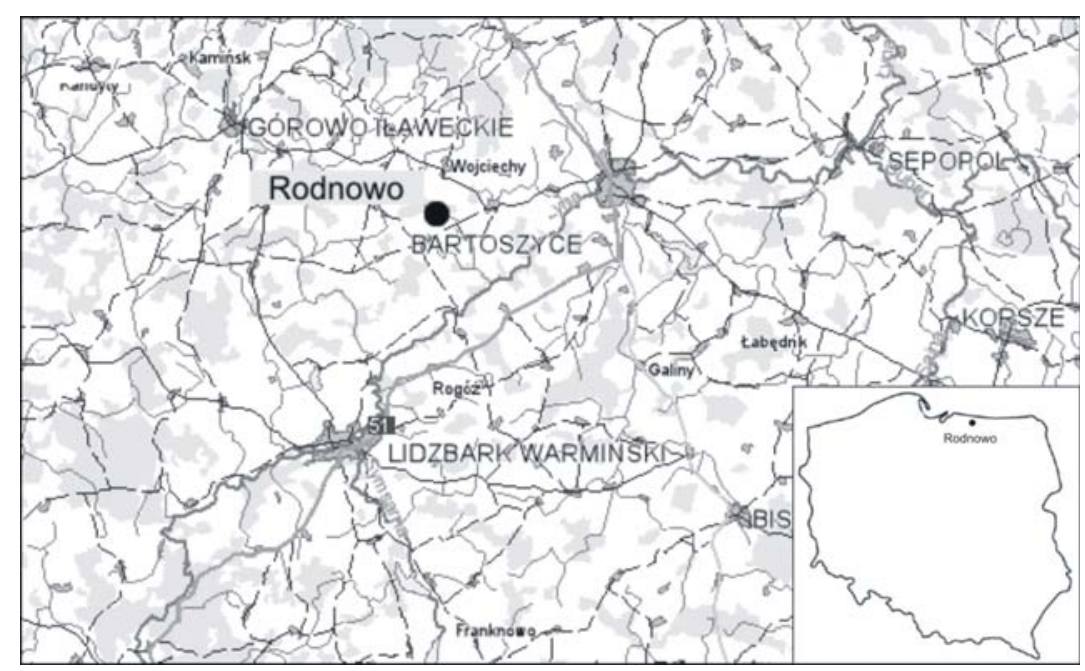

Fig 1: Locality of the surveyed population of $L$. incisum

The population was placed in the field of winter wheat, near the roadside, in a plant community of Vicietum tetraspermae from the allion Aperion spicae-venti (Matuszkiewicz 2001). All specimens were collected in a 3m to $3 \mathrm{~m}$ grid (Fig. 2.). Depending on specimen concentration two to seven specimens from each grid were collected for genetic analysis. Together 24 specimens were took into research that is almost half of the surveyed location. As the individuals picked for this research may be regarded as a representative sample for a whole site, we can conclude about genetic diversity within the population.

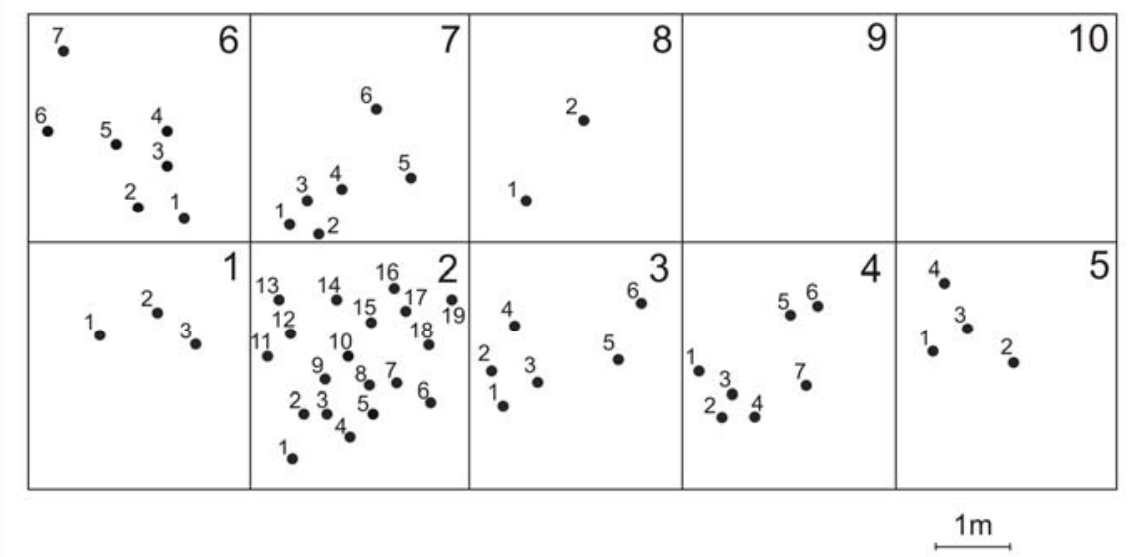

Fig 2: Distribution of $L$. incisum individuals of the researched population in a grid of $3 \times 3 \mathrm{~m}$. Number of a grid is put in a right upper corner. 
Total genomic DNA was extracted from 24 collected individuals. DNA was isolated by the modificated CTAB procedure (Doyle and Doyle 1990). The isolated DNA was dissolved in water and stored at $-20^{\circ} \mathrm{C}$.

In order to investigate the genetic variability of the selected population markers of ISSR (inter-simple sequence repeats) category were used. Primer sequences used for DNA amplification are listed in the table (Tab. 1). ISSR markers show polymorphism of DNA fragments located between microsatellite regions using as primer sequences (Ziętkiewicz et al. 1994). The target sequence of ISSR markers does not require prior identification what makes these markers especially useful in the case of species for which species-specific amplification starters for microsattelite loci (SSR-simple sequence repeats) have not yet been defined (Szczecińska et al. 2009). Used primers are relatively long (16-25 bp), what has an effect in a high specifity of the reaction. (Ziętkiewicz et al. 1994). Inter-simple sequence repeats have successfully been used to assay genetic variability among cultivated plants as well as for population genetic studies in natural plant populations. (Wolfe et. al. 1998, Li \& Jin 2008) because of their high level of polymorphism and reproducibility (Wolfe et al. 1998, Bornet and Branchard 2001). ISSR are a suitable marker to identify polymorphic loci among closely related specimens including classification of inbred lines in breeding programs (Kantety et al. 1995).

Tab 1: ISSR primers used in studies on Lamium with number of amplificated loci.

\begin{tabular}{|c|c|c|c|}
\hline Primer & Primer sequence & bp & Number of amplificated loci \\
\hline ISSR-807 & 5' AGAGAGAGAGAGAGAGT 3' & 17 & 13 \\
\hline ISSR-810 & 5' GAGAGAGAGAGAGAGAT 3' & 17 & 21 \\
\hline ISSR-825 & 5' ACACACACACACACACT 3' & 17 & 15 \\
\hline
\end{tabular}

The PCR reaction was carried out in $20 \mu \mathrm{l}$ of reaction mixture composed of $0,7 \mu \mathrm{l}$ DNA, $2 \mu$ reaction buffer, $1 \mu \mathrm{l}$ primer, 0,4 $\mu \mathrm{l}$ dNTP (dATP, dGTP, dCTP, dTTP), $1 \mu \mathrm{l} \mathrm{BSA}(0.25 \mathrm{mg} / \mathrm{ml})$ and 1 U polymerase (YellowTaq EURx). ISSR marker reactions were performed under the following conditions: (1) initial denaturation $-4 \mathrm{~min}$. at a temperature of $94^{\circ} \mathrm{C}$, (2) denaturation $-1 \mathrm{~min}$. at $94^{\circ} \mathrm{C}$, (3) annealing $-1 \mathrm{~min}$. at $49^{\circ} \mathrm{C}$, (4) elongation $-1.5 \mathrm{~min}$. at $72^{\circ} \mathrm{C}$, (5) final elongation $-7 \mathrm{~min}$. at $72^{\circ} \mathrm{C}$. Stages $2-4$ were repeated 34 times. For ISSR 810 annealing temperature was risen to $51^{\circ} \mathrm{C}$.

The products of the ISSR-PCR reaction were separated on $2 \%$ agarose gel, followed by DNA staining with ethidium bromide. After rinsing in deionised water, agarose gel was analysed in a transilluminator under UV light and photographed.

\section{Results}

The analysis of chosen individuals with use of three ISSR primers revealed total of 49 loci. The numbers of loci amplified by each primer are given in Table 1 . The highest number of bands (21) was scored for primer ISSR-810. With ISSR-807 and ISSR-825 13 and 15 loci were amplified, respectively. All of loci amplified with ISSR-825 primer were monomorphic (Fig. 3.) while the analysis with use of ISSR -807 primer revealed only two polymorphic loci. The biggest number of polymorphic loci were scored for ISSR-810 (13 amongst 21 amplified loci). The mean level of polymorphism in the population was relatively low $(\mathrm{P}=34.04 \%)$.

Genetic diversity expressed by Nei's gene diversity index $\left(\mathrm{H}_{\mathrm{E}}=0.099\right)$ corresponded with the mean number of alleles per locus $\left(A_{E}=1.160\right)$. Relatively low values reached by each of the coefficients indicate that the analyzed population was not much genetically diversified. The Shannon information index $\left(\mathrm{I}_{\mathrm{S}}\right)$ reached the value of 0.153 on average.

\section{Discussion}

Rare plant species are commonly hypothesized to have little genetic variation because of changes in allelic frequencies caused by chance events (small population size, founder effect or bottleneck effect), strong and directional selection toward genetic uniformity, inbreeding or other factors. On the other hand, only a few studies have reported a complete absence of genetic variability for rare or very locally distributed plant species (Lee et al. 2002). For example, the narrow endemic Torrey pine (Pinus torreyana) displayed no variation within each of two studied populations, and only slight differences between them, despite the fact that pines generally show high levels of variation (Ledig \& Conkle 1983). Red pine 
(P. resinosa), which in contrast to Pinus torreyana is widely distributed throughout much of the northeastern United States and adjacent regions in Canada, is also remarkably uniform with respect to both allozymes and RAPDs (Mosseler et al. 1992). An endemic tree Berchemia bercheniaefolia (Rhamnaceae) examined with ISSR markers showed no polymorphism both within and between four investigated local populations. All of this species were affected by the genetic bottleneck in their history. In the case of $B$. bercheniaefolia the bottleneck effect was additionally combined with the fluctuation of local population sizes due to human activities (Lee et al. 2002). The genetic bottleneck is one of the main factors affecting genetic diversity and changing allele frequency (Lomnicki 2002, Young et al. 1999). The low level of genetic diversity observed in the researched L. incisum population in conjunction with a small area occupied by it might be an evidence of a small effective population size or is an argument for a significant decrease of population size in a recent past. Nevertheless it has to be remembered that bottleneck effect isn't easy to identify undoubtedly as genetic effects of this process depend on the size of population contraction and on the rate of its regeneration (Freeland 2008).

The coefficients of genetic diversity in the analyzed population were similar to the values noted in research on Chamaedaphne calyculata which is also a rare species. ISSR and ISJ markers used in that study showed similar genetic diversity at population level $(\mathrm{P}=27.6 \%$, $\mathrm{AE}=1.17, \mathrm{HE}=0.098$ ) (Szczecińska et al. 2009). The low genetic diversity in the examined $L$. incisum population, which is indicated by the analyzed parameters, the most probably is due to genetic drift. Genetic drift is a process which causes changes in allele frequency from one generation to another. The drift modifies allele frequency in a random way causing changes with no adaptative ground. Genetic drift may lead to very significant modification in frequency of alleles in a single population. Its effect is the hardest in small populations where is no selective pressure. Random processes take effect in the extinction of some alleles and fixation of others in a relatively short time. The result is that individuals in later generations are more likely to carry alleles that are copies of the same ancestral alleles. In small populations the drift may quickly lead to the loss of genetic diversity and homozygosity (Lomnicki 2002, Freeland 2008). Considered L. incisum population despite being the most numerous from all known to the authors, still is relatively small. Because of that significant effects of genetic drift should be anticipated.

The uniformity of genotypes is also supported by inbreeding. This process caused by mating closely related individuals may become prevalent, especially in small and isolated populations with a low level of gene flow. Immigration of pollen or seeds from distant population may result in the addition of new genetic variants to the established gene pool and prevent the inbreeding process (Freeland 2008, Höglund 2009). In the case of L. incisum seed migration is limited because of relatively heavy nutlets adapted to myrmecochory. For bigger distances they can be dispersed by antropochory. Therefore the most important way of gene flow for this species is pollen transport. In widely dispersed populations the chance for pollinating with pollen from distant sites is smaller. Mating within one population is more probable in this case.

Inbreeding reaches very high level in populations of plants which are self-fertilizing (Höglund 2009). There are numerous plant species following this reproductive strategy, which flowers don't have any adaptation to avoid self-pollination. Autogamy is common in many crop plants e.g. wheat and barley, however it happens even in plants adjusted to insectpollination like species from genus Epipactis, Cephalanthera, Neotia or Viola. This strategy is beneficial especially in a situation when cross-pollination is hardly effective (Galera 1998). A particular case of self-fertilization are plants with cleistogamous flowers. In Lamium such a kind of flowers which produced viable seeds as a result of autogamy were observed in L. amplexicaule. (Baskin \& Baskin 2001). Probably the self-fertilization occurring in 
L. amplexicaule isn't a solitary case in the genus. Cleistogamy was sporadically met in $L$. purpureum and L. incisum as well (author's observation) what implies these species are insect-pollinated with proclivity towards self-pollination. In the researched population of $L$. incisum the process of self-fertilization also may take place causing the loss of genetic variation. Under certain circumstances, especially in small populations, inbreeding may lead to inbreeding depression. It is caused by cumulative effects of genetic drift which reveals unfavorable alleles in populations (Hamrick and Godt 1996) and decreases fitness and vigor of all individuals in terms of survival, growth and fertility (Lee S.-W. 2002, Höglund 2009). On the other hand inbreeding may have any fitness consequences and need not be harmful to populations. During inbreeding or during population-size bottlenecks, much of genetic variation is lost and along with a general loss of genetic variation the deleterious recessives variation is also lost. That is why inbreeding is not always connected with inbreeding depression (Höglund 2009). Concluding from obtained results we can't say for certain if the fitness of the population decreased. We can only hypothesize that low genetic diversity delimits adaptability for environmental changes and indirectly might be a reason for lessening its size.

\section{References}

Baskin C. \& Baskin J. (2001): Seeds. Ecology, Biogeography, and Evolution of Dormancy and Germination. Academic Press, 667pp.

Bornet B. \& Branchard M. (2001): Non anchored inter simple sequence repeat (ISSR) markers: reproducible and polymorphic tools for genome fingerprinting.- Plant Molecular Biology Reporter 19: 209-215.

Doyle J. J. \& Doyle J. L. (1990): Isolation of plant DNA from fresh tissue.- Focus 12: 13-15.

Freeland J. R. (2008): Ekologia molekularna. Wydawnictwo Naukowe PWN, Warszawa 2008, 356s.

Galera H. (1998): Samozapylenie - sukces, czy porażka? Wiedza i Życie, 1998/7.

Hamrick J.L. \& Godt M.J.W. (1996): Conservation genetics of endemic plant species. In. Avise J.C. and Hamrick J.L. (eds.): Conservation genetics: case studies from nature, Chapman and Hall, New York, USA, pp 281-304

Höglund J. (2009): Evolutionary Conservation Genetics. Oxford University Press, 189pp.

Kantety R., Zeng X., Bennetzen J. \& Zehr B. (1995): Assessment of genetic diversity in dent and popcorn (Zea mays L.) inbred lines using inter-simple sequence repeat (ISSR) amplification.- Molecular Breeding 1:365-373.

Korniak T. \& Hołdyński Cz. (1987): Jasnota mieszaniec (Lamium hybridum Vill.) w północno-wschodniej Polsce.- Zeszyty naukowe akademii rolniczej im. H. Kołłąaja w Krakowie, 216: 149-156.

Ledig F.T. \& Conkle M.T. (1983): Genetic diversity and genetic structure in a narrow endemic, Torrey pine (Pinus torreyana Parry ex Carr.).- Evolution 37: 79-85.

Lee S.-W., Kim Y.-M. \& Kim W.-W. (2002): Lack of allozyme and ISSR variation in the rare endemic tree species, Berchemia berchemiaefolia (Rhamnaceae) in Korea.- Ann. For. Sci. 60: 357-360.

Li J.-M. \& Jin Z.-X. (2008): Genetic structure of endangered Emmenopterys henryi Oliv. basedon ISSR polymorphism and implications for its conservation.- Genetica (2008) 133: 227-234.

Łomnicki A. (2002): Dobór, dryf i inne czynniki kształtujące częstość genów. In. Krzanowska et al.: Zarys mechanizmów ewolucji . Wyd. Naukowe PWN, Warszawa, p. 154-214.

Matuszkiewicz W. (2001): Przewodnik do oznaczania zbiorowisk roślinnych Polski. PWN. Warszawa.

Mennema J. (1989): A taxonomic revision of Lamium (Lamiaceae). Universitaire Pers Leiden. Leiden 196 pp.

Mosseler A., Egger K.N. \& Hughes G.A. (1992): Low levels of genetic diversity in red pine confirmed by random amplified polymorphic DNA markers.- Can. J. For. Res. 22 (1992) 1332-1337.

Szafer W., Kulczyński S. \& Pawłowski B. (1986): Rośliny polskie. PWN, Warszawa: 576-577.

Szczecińska M., Sawicki J., Wąsowicz K., Hołdyński Cz. (2009): Genetic variation of the relict and endangered population of Chamaedaphne calyculata (Ericaceae) in Poland.- Dendrobiology 62: 23-33.

Taylor R. (1991): The Origin of Lamium hybridum, A Case Study in the Search for the Parents of Hybrid Species.- Northwest Science, Vol. 65 No.3: 116-124.

Vrijenhoek R.C. (1994): Unisexual fish: model systems for studying.- Annual Reviev of Ecology and Systematics 25: 71-96.

Warcholińska A. (1993): Chwasty polne Wzniesień Łódzkich.-Atlas rozmieszczenia. Wyd. Uniwersytetu Łódzkiego, Łódź. 
Wolfe A.D., Xiang Q-Y. \& Kephart S.R. (1998): Assessing hybridization in natural populations of Penstemon (Scrophulariaceae) using hypervariable intersimple sequence repeat (ISSR) bands.- Molecular Ecology 7: 1107-1125.

Young A., Boyle T. \& Brown T. (1996): The population genetic consequences of habitat fragmentation for plants.- TREE vol. II. 10: 413-418.

Zając A. (1988): Badania nad pochodzeniem archeofitów wystęujących w Polsce. Część IV. Taksony pochodzenia pontyjsko-pannońskiego, śródziemnomorsko-południowo-azjatyckiego, południowoazjatyckiego i środkowoeuropejskiego. Archaeophyta anthropogena, Archaeophyta resistentia. Archeofity o nieznanym pochodzeniu. In Kornaś J. (red.) Zeszyty Naukowe Uniwersytetu Jagiellońskiego. Prace botaniczne - zeszyt 17: 23-52.

Ziętkiewicz E., Rafalski A. \& Labuda D. (1994): Genome fingerprinting by simple-sequence repeat (SSR) anchored polymerase chain reaction amplification.- Genomics 20: 176-183.

Authors' addresses: Katarzyna Wąsowicz, Monika Szczecińska \& Jakub Sawicki, Department of Botany and Nature Protection, University of Warmia and Mazury in Olsztyn, Plac Łódzki 1, 10-727 Olsztyn, Poland, e-mail: katarzyna.wasowicz@uwm.edu.pl

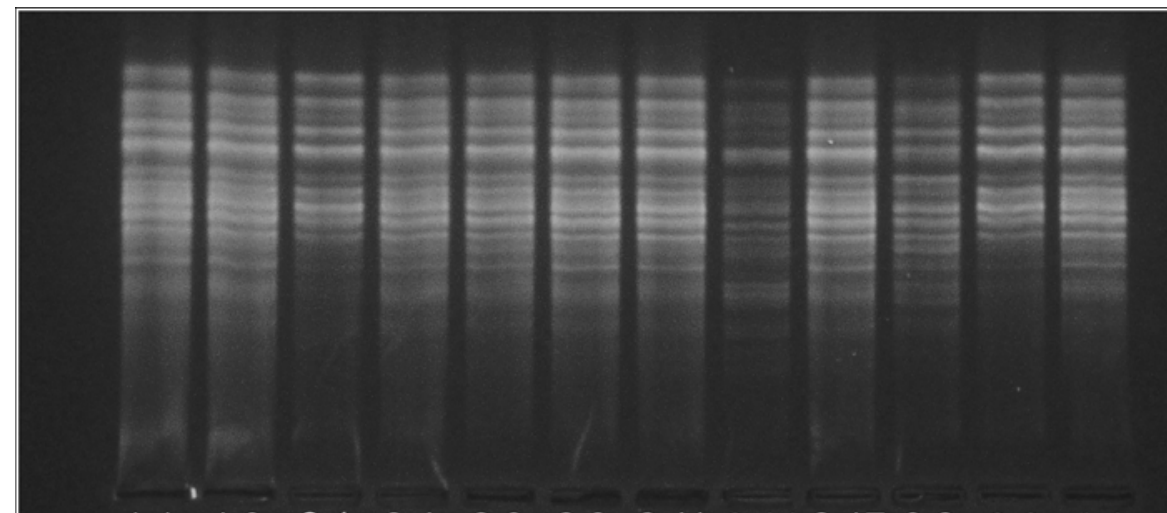

$\begin{array}{lllllllllllll}1.1 & 1.3 & 2.1 & 2.4 & 2.6 & 2.8 & 2.11 & 2.14 & 2.17 & 3.2 & 3.6 & 4.1\end{array}$

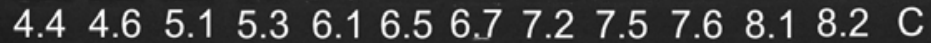

Fig 3: DNA amplification pattern for Lamium incisum with ISSR-825 primer (the digit before a comma means grid number, after that comes number of an individual; $\mathrm{C}$ is a control for L. purpureum) 